\title{
Bricolage, Collaboration and Mission Drift in Social Enterprises
}

Caleb Kwong (corresponding author)

Essex Business School, University of Essex, United Kingdom

Email: ckwong@essex.ac.uk

Tel: 44 (0) 1702328394

Misagh Tasavori

Essex Business School, University of Essex, United Kingdom

Cherry Wun-mei Cheung

London South Bank University, United Kingdom 


\title{
Bricolage, Collaboration and Mission Drift in Social Enterprises
}

\begin{abstract}
Increasingly, social enterprises are relying on collaboration with partners to tackle the resource constraints that they face. In this research we focus on the strategy of bricolage to explore whether and how the different types of partner becoming involved may impact on the mission of social enterprises. Grounded in resource dependency and transaction cost theories, we explore how power asymmetry and the nature of involvement may impact on the outcomes of bricolage. Our findings demonstrate that in the more integrated relationships with high power asymmetry, more instances of mission drift might be observed compared to when social enterprises develop the more collaborative or complementary nature of partnerships with symmetrical power dependency, or when the partners' involvements are mainly transaction-based.
\end{abstract}

Keywords: social entrepreneurship, social enterprise, bricolage, mission drift, collaboration 


\section{Introduction}

Bricolage has long been recognised in the entrepreneurship literature as an important strategy to tackle resource constraints in penurious contexts (e.g., Garud and Karnøe 2003; Stinchfield, Nelson, and Wood 2013; Baker and Nelson 2005; Baker, Miner, and Eesley 2003). Increasingly, the concept of bricolage is seen as particularly applicable to the social sector context as its implementation enables social enterprises to expand their products and markets beyond what they would have been able to create in the first place (Desa 2012; Di Domenico, Haugh and Tracey 2010). Bricolage may involve no collaboration and be internal, in which case the social enterprise augments and reconfigures its resources at hand for a new purpose, or it may be collective, involving the utilisation of resources from external partners and together co-creating a joint initiative (Baker and Nelson 2005; Duymedjian and Rüling 2010). Although previous studies have found collaboration to be mutually beneficial as it improves access to resources (Shaw and de Bruin 2013), and facilitates knowledge and information exchange (Chalmers and Balan-Vnuk 2013) as well as aiding the building of project legitimacy (Huybrechts and Nicholls 2013), little attention has focused on the impact of bricolage on the pursuit of social enterprises' missions in terms of changes in market and product.

Whilst collective bricolage can be fruitful by providing access to partners with resources (Duymedjian and Rüling 2010), the theories on resource commons have long highlighted the danger of partnerships involving open collaboration and resources sharing (Hardin 1969; Olsen 1965). This could create disagreements and conflicts, particularly when goal incongruence occurs between the parties concerned. In such cases, collaboration becomes both a power and transactional relationship, whereby those who are more dependent on the resources of others would be in a worse bargaining position (Frooman 1999). Drawing on resource dependency theory (RDT) and transaction cost theory, our research explores how the involvement of different types of partners, in terms of the resource dependency relationship and the nature of 
the partner's involvement, affects their market and product emphases and, in turn, creates changes in the mission of the social enterprises. We define involvement broadly as participation in a partnership with another entity with the intention of creating a social impact, regardless of the extent, depth and breadth of such partnership.

Our study adopts a qualitative approach through interviewing key personnel from nine social enterprises in the UK. An event-based approach is adopted whereby respondents were asked to recall each incident that they would consider as bricolage, and further discuss the nature of these events, the parties involved, internal and external resources utilised, and the impact on the missions of social enterprises. We believe that our study offers a number of unique insights into how social enterprises can combat the resource scarce environment that they face, through bricolage and collaboration. As far as we are aware, this study is also the first to explore how collaboration may influence the outcomes and mission drift of bricolage. Through the theoretical lens of resource dependency and transaction costs theories, our study highlights the ways in which the outcomes of bricolage may be affected by the different resource relationships social enterprises have with their partners.

The rest of the paper is structured as follows. First, the theoretical background of the research is explained. Then, a methodology section and the results of our analysis are presented. The paper then continues with a discussion of results and conclusions.

\section{Theoretical Background}

\section{Bricolage Theory}

The term 'bricolage' was first coined by Levi-Strauss $(1967,17)$ as “making do with whatever is at hand" to contrast with the strategy of optimisation involving the acquisition of high quality resources that have proven capabilities for the specific application for which the resources are 
intended (Desa and Basu 2013). Resources are "all assets, capabilities, organisational processes, firm attributes, information, knowledge" (Barney 1991, 101) that can be obtained by a social enterprise. Resources used in the bricolage are usually available at a low cost or even free of charge because others think that they cannot be used or are substandard. With the bricolage strategy, the entrepreneurs attempt to 'recycle' pre-existing resources and combine and reuse them (Baker and Nelson 2005; Di Domenico, Haugh, and Tracey 2010). For example, a social enterprise business model might be based on collecting unwanted donated items of furniture from their owners, refurbishing them and then reselling them. Thus, bricolage involves the deployment and integration of discarded, disused, or unwanted resources at hand, be it physical artefacts, skills or ideas, in novel ways rather than conforming to the norms and standard practices originally intended (Jayawarna Jones and MacPherson 2014; Baker and Nelson 2005). Bricolage is particularly relevant in a penurious context where, under severe resource constraints, the bricoleurs refuse to let the unavailability of high quality resources limit his or her actions (Senyard et al. 2014; Fisher 2012). Because of this, the concept of bricolage is emerging as a major theoretical lens in understanding the resource utilisation strategies of social enterprises, with previous studies highlighting its enabling effect on social value creation and addressing social problems beyond what they would have been able to create in the first place (Desa 2012; Basu and Desa 2014; Di Domenico, Haugh and Tracey 2010).

While the reliance on resources at hand echoes Penrose's (1959) notion of the crucial role of the internal resources of a firm, bricolage can also be collective, involving the utilisation of resources from external partners and together co-creating a joint initiative that can be mutually beneficial (Duymedjian and Rüling 2010). The term 'at hand' has been expanded in previous studies to include resources that are readily available from elsewhere (Baker and Nelson 2005). This could mean utilising hidden or untapped local resources that other parties fail to recognise, value, or adequately use, and allows the organisation to thereby acquire them 
cheaply (Di Domenico, Haugh and Tracey 2010). Resources at hand can also include resources obtained from collective bricolage whereby organisations collaborate with other organisations (Duymedjian and Ruling 2010). The crucial role of utilising external resources is highlighted by Baker and Nelson's (2005) notion of selective bricolage, which suggests that a combination of resource reconfiguration and acquisition enables organisations to break away from their preexisting norms and practices to extend or transform the venture away from the originally intended path (Feldman 2000; Teece, Pisano, and Shuen,, 1997). In turn, this provides organisations with a platform to strategically engage in more radical, far-reaching and innovative activities with higher growth potential (Baker and Nelson 2005).

As a process, bricolage is rarely planned, but as bricoleurs increasingly understand both the internal knowledge and resource capacities of their organisation as well as the external context, they often improvise by assembling an original composition of business ideas that stretch their existing resources to the full (Weick 1998). The concept is closely related to improvisation, or the convergence of design and execution (Baker, Miner, and Easley 2003; Senyard et al. 2014). To do so, organisations draw heavily on both procedural and declarative organisational memory (Moorman and Milner 1998), as well as utilising resources-at-hand that have often been accumulated on the principle that 'they may always come in handy' (Di Domenico, Haugh, and Tracey 2010, 689), rather than acquired in response to the demands of a current project (Lanzara 1999, 1998).

\section{Bricolage and Its Impact on Social Enterprises’ Mission}

Bricolage denotes ongoing augmentations and reconfigurations with change being an inevitable consequence (Lanzara and Patriotta 2001). Each individual bricolage activity can lead to changes in product and market emphases. For instance, bricolage can lead to the development of new or more efficient products, as in the cases of the impoverished BMW and 
Heinkel in the post-war jet propulsion technology race whereby the use of existing technologies significantly reduced the time and resources that their developments required (Scott, 1995; Parker and Fedder 2016), or similarly the collective approach taken by the Danish wind turbine industry against the US giants through collaboration and the utilisation of scrap resources (Garud and Karnøe 2003). Alternatively, bricolage could induce change towards new markets, for instance, by introducing existing products, processes or activities into a new market catchment where a high level of unsatisfied demand is noted, as in the case of multinational enterprises targeting the 'bottom of the pyramid' market through augmenting their existing products to create their low-cost varieties (Halme, Lindeman, and Linna , 2012; Tasavori, Ghauri, and Zaefarian 2014, 2016; Tasavori, Zaefarian, and Ghauri 2015; Ghauri, Tasavori, and Zaefarian 2014)..

As bricolage often involves continuous improvisation and change, it may also have long term implications in relation to a change of mission. The theory of path dependence (Sydow Sydow, Schreyögg, and Koch 2009; Garud, Kumaraswamy, and Karnøe 2010) suggests that these changes in product and market emphases may result in organisations changing their path and trajectory, as new knowledge, competencies and resources that have been acquired from the new activity can be further utilised by new activities that are different from those they originally intended (Garud, Kumaraswamy, and Karnøe 2010). Tasavori, Kwong, and Pruthi (2016) suggest that whilst a single incremental change on its own may not result in a drastic change in social mission, the change may affect the future direction in the types of social activities that a social enterprise may embark upon. In the long run, therefore, bricolage could mean that the resulting activity pursued is different from what was originally intended, and these changes could have both positive and negative consequences. Changes in the product and market emphases within organisations can be considered favourable if they can allow organisations to respond to the new challenges and to overtake competition from innovative 
competitors (O'Reilly III and Tushman 2011). When successful, these changes enable firms to increase their market share and move onto the path of further growth and expansion. However, the danger is when the organisation embarks on the 'wrong' type of change, for instance, by choosing products or innovations to invest in that do not reach their intended targets, resulting in irreversible falls in market share as well as revenues (O'Reilly III and Tushman 2011). In addition, social enterprises will be especially concerned with the undesirable social consequences associated with change. In particular, changes in products and services arising from the increasing emphases on earned income and financial sustainability may result in social enterprises moving on to target catchments that are deemed more financially rewarding, and ceasing to serve those they originally intended to serve (Weisbrod 2004; Jones, 2007; Dey and Steyaert 2012). Diverting from their mission may result in their legitimacy being challenged, which in turn affects their ability to attract financial and other forms of support from donors and other philanthropists (Brinkerhoff 2002; Weisbrod 1997).

\section{Collective bricolage for social enterprises in the social and solidarity economy}

Whilst internal bricoleurs may freely constitute, develop and enrich their personal stock and knowledge and affect how the resources are being utilised for bricolage purposes, collective bricolage is a process of emergent co-shaping involving interaction and constant mutual adjustment between the parties involved (Garud and Karnøe 2003; Duymedjian and Rüling 2010). Collective bricolage offers economies of scale, by enabling financially-strapped social enterprises the potential to expand both in size and in scope, in doing so providing them mutual protection against risks. However, collective actions could create challenges to resource holders' autonomy to exercise ownership. Olson's (1965) logic of collective action and Hardin's (1968) tragedy of the commons both highlight the problem of free-riders exploiting those who made available their own resources for others. To overcome this, later work, including that from Ostrom (1990) and Bauwens (2005), considered how societies have 
developed common resource pools which can be regulated and upheld by diverse institutional arrangements and principles. Ostrom (1990) sees appropriation, including the uses of wellcommunicated rules, bottom-up monitoring and peer sanctions, as crucial in the governance of group-owned common resources. Such appropriation would ensure resource holders remain involved in the co-shaping process, while reaping additional benefits from the co-created outcome. In contrast, Bauwens (2005) explores the recent peer-to-peer phenomena and found that most of these peer-production initiatives apply a much looser regulatory framework. These initiatives include the Creative Commons - a global initiative to licence intellectual property that offers public access, and Wikipedia, the open-source encyclopaedia (Ridley-Duff and Bull 2015). Bauwens (2005) observes that, by being able to utilise an enriched pool of common knowledge, participants of open-source and open-cooperation initiatives could benefit from the elevated knowledge platform facilitating further knowledge development. The no-strings attached approach also means that dissolution can be straightforward and relatively pain-free, when missions become no longer compatible. An example would be the split in the International Fairtrade Movement, with the US faction intending to further engage with corporate sponsors such as Starbucks which pushes them towards the use of larger-scale plantations, and away from their intended recipients of small farmers (Utting 2013).

Within the social entrepreneurship literature, a new perspective is beginning to emerge whereby social enterprises should no longer be seen as separate and competing entities, but instead as part of a social and solidarity economy striving for a broad but integrated approach towards social justice and equality (Ridley-Duff 2012, 2015). The social and solidarity economy perspective offers a new lens to re-examine the role of social enterprises within the social economy, potentially to move away from the traditional solidary approach of operation towards a much more cohesive view of societal needs based on collective consensus and common interests (Fonteneau et al., 2011). For the social and solidarity economy to be 
sustained, collective actions should connect at multiple levels via networks, movements and alliances. As suggested by Ostrom (1990), good governance, strong advocacy and extensive negotiation are required to enable the separate entities to scale-up on terms compatible with their values and objectives (Utting 2013). It is also becoming a trend for social enterprises to move towards open sources and open cooperation, similar to that mentioned by Bauwens (Ridley-Duff and Bull 2015). In the light of these developments, there is an increased attempt amongst practitioners and academics to explore new forms of partnership and not be limited to past cooperatives and mutual societies. Collective bricolage fits well into this trend, as it involves the pooling of resources between resource holders to ensure the creation of novel products and activities.

Nevertheless, as the transfer of privately-held resources to a 'common pool' effectively required resources holders to relinquish a degree of control over resources that they owned, a multi-stakeholder approach to governance would be required in accordance with Ostrom (1990). As the difference in input amongst the different partners results in the hybridisation of reciprocity, a degree of negotiation between partners would be unavoidable. Yet, how ownership of resources may dictate the power dynamic as well as the co-created outcomes of collective bricolage is not yet fully understood. Studies have suggested that the eventual outcomes co-created would be determined by a number of factors, including the type of production and allocation functions, the predictability of resource flow, the scarcity of the resources, the size of the partnerships involved and their dependence on each other's resources (Olson 1965). It is therefore important to further understand the mechanisms behind different partnership structures under collective bricolage, and how social enterprise could exert some degree of control, through negotiation, monitoring and supervision, in ensuring that their mission will continue to be fulfilled by the co-created outcome. In this research, we focus on two aspects of collaboration that may affect the nature of bricolage activities as well as their 
outcomes: first, their resource dependency, and second, the nature of partnership, both of which are discussed below.

\section{Resource Dependency Theory}

According to RDT, companies require resources to survive, and have to establish relationships with organisations that possess those resources (Pfeffer and Salancik 1978; Pfeffer and Salancik 2003). Therefore, organizations are dependent upon their environments. According to Jaffee (2001), resource-dependency theory "emphasizes proactive strategies that can be pursued to deal with environmental constraints [rather than] viewing organizations as largely passive or impotent in relation to environmental forces" (Jaffee 2001, 218). Power and its inverse, dependence, are key concepts in this theoretical perspective to understand interorganisational relationships.

Power is defined as "the ability to bring about the outcomes of desire" (Salancik and Pfeffer 1974,3$)$ that one party may possess over another, which in turn dictates the dynamic between them. RDT stipulates that resources ownerships, including but not limited to finance, physical infrastructure, human capital and labour, provide resource holders with a strong position in the exchange bargaining process (Pfeffer and Salancik 2003; Pfeffer and Salancik 1978). According to RDT, it is the balance of power within that relationship that determines the power distribution (Frooman 1999). Asymmetrical power distribution within an exchange relationship would, in the situation of goal incongruence, result in one side having greater ability to bring about their desired outcome at the expense of the other (Pfeffer and Salancik 1978). The resulting power relation then has an effect on the choice of strategies that an organisation may undertake, even if elements of the new strategies go against its preference (Weisbrod 1998). The RDT relationship can also be sequentially dependent, bringing about the question of enforceability (Alter and Hage 1993), which can be controlled though coercive, 
motivational and normative mechanisms (Etzioni 1975). Negotiation and persuasion may also be necessary when the power relationship is either unbalanced or unclear (Di Domenico, Haugh, and Tracey 2010). On the other hand, power can be symmetrical when the exchange process is considered to be dyadic and mutually dependent (Frooman 1999). In such a case, both parties would have an equal opportunity to influence their shared objectives, processes and outcomes (Brinkerhoff 2002).

Nature of Involvement and Its Impact on Social Enterprises' Mission Alongside resource dependence, whether a partner can influence the mission of a social enterprise is also dependent on the nature of its involvement. Austin (2000) discusses the collaboration continuum of nonprofit organisations whereby partnership can be divided into clear stages. On the one hand, it can be characterised by a transactional and sometimes philanthropic nature. The transaction cost theory (Williamson 1973) emphasises working with partners as the mechanism both to increase resources and reduce transaction costs, and in doing so maximising the economic benefits to both parties concerned (Foster and Meinhard 2002; Sharfman, Gray, and Yan 1991). Such transactions could range from a donor-recipient relationship, such as when a commercial organisation uses such a partnership with a social enterprise to fulfil their corporate social responsibilities (CSR), to resource exchanges focusing on specific cause-related activities (Austin 2000). In these cases, the emphasis of partnership is on the benefits of a transactional relationship based on the economic law of exchange (Harbaugh 1998). Such benefits may be available because the partner's own objective is compatible with the social enterprise's mission, or because they had little interest in the details of execution, and therefore view the latter as an effective agent to carry out their own mission. Alternatively, it may be due to a partner's lack of legitimacy to intervene (Mitchell, Agle, and Wood 1997; Hill and Jones 1992). In the case of a transactional relationship, the partner has little intention or ability to control 
how the resource is being utilised (Austin 2000). Such a transactional arrangement provides social enterprises with a greater level of autonomy with fewer interactions being expected.

On the other hand, for partnerships that are intending to co-create common social values, involvements are likely to be integrated where the partners are likely to take a keen interest in the outcomes as well as in the future direction of the project or projects that they have been co-involved in (Austin 2000). In some of these cases, there may be a convergence of mission where staff and resources are merged for collective actions (Seitanidi, Koufopoulos, Palmer 2010). In other cases, the partner may be more hands off, but is nevertheless very keen on ensuring that their own objectives are being well-served in the integrated project and thereby on imposing strict conditions on the usage of their resources (Kaine and Green 2013). Keen interest often leads to more frequent interaction, communication and joint decision making (Brinkerhoff 2002). Partners are also more likely to intervene in the operation of the project, particularly when there is a concern that their own objective may not be fulfilled (Ebrahim 2002).

We propose that resource dependency relationship and the nature of partnership can be seen as two continuums, which enables us to come up with the following $2 \times 2$ matrix (Figure 1).

$* * *$ Insert Figure 1 about here $* * *$

Four types of partners can be identified. Dormant partner refers to those whose resources are being asymmetrically relied on by the social enterprise, but have only transactional involvement in the social enterprise's operation. Complementary partner refers to those who hold a symmetrical resource dependence relationship with the social enterprise and have a transactional involvement in its operation. Collaborative partner refers to those who hold a symmetrical resource dependence relationship with the social enterprise and have an 
integrative involvement in its operation. Dominant partner refers to those who hold asymmetrical power over a social enterprise and have an integrated involvement in its operation.

\section{Conceptual Framework}

Combining the reviewed literature in relation to bricolage, RDT and nature of involvement, the following conceptual framework can be proposed (see Figure 2). As is illustrated in Figure 2, social enterprises may engage in two types of internal bricolage and collective bricolage to pursue their mission. As discussed before, in collaboration with other organisations in collective bricolage, social enterprises may have partners with symmetric/asymmetric power. The relationship of social enterprises with partners in each of these categories might then be based on integrated or transactional involvement.

$$
\text { ***Insert Figure } 2 \text { about here*** }
$$

\section{Methodology}

\section{Research Design and Data Collection}

The questions studied in this research are i) how the involvement of different types of partners (based on the resource dependency relationship and the nature of the partner's involvement) play a role in the market and product expansion of social enterprises and ii) how different types of partnerships impact the mission of the social enterprises. In the social entrepreneurship context where few studies have examined these questions, a qualitative multiple case study design was pursued to extend theory into this context (Graebner, Martin and Roundy 2012) and to generate new theoretical and managerial insights (Yin 2012). Multiple cases permit replication logic (Yin 2012) and lead to more robust, generalizable theory than a single case (Eisenhardt and Graebner 2007). 
Nine social enterprises in the UK that we have connections with were selected and interviewed. The context of the UK is relevant, as in recent years, social enterprises have seen a reduction in the amount of public funding (Meegan et al. 2016) as well as an economic downturn which has impacted on their access to resources. The UK government defines 'social enterprise' as "a business with primarily social objectives whose surpluses are principally reinvested for that purpose in the business or in the community, rather than being driven by the need to maximise profit for shareholders and owners" (DTI 2003, 6). Using the EMES framework from the ICSEM study (Defourny and Nyssens 2016), all but three of the social enterprises can be considered 'enterprising non-profits' that rely on earned income in supporting their pre-defined social mission. Two others can be considered as 'social businesses' that incorporate business practices and create financial surplus to support their social mission (Smith, Cronley, and Barr 2012). This is sometimes referred to as pursuit of dual/hybrid mission and blended value creation (Brooks 2009). The attempt to combine both social and economic mission and balance these two apparently contradictory missions (Zahra et al. 2009) in social enterprises offer a unique context to study (Grimes and Victor 2009).

We define mission drift as the change of social mission from that originally stated. The purpose of a social mission is to provide "employees and stakeholders with clarity about what the organisation is fundamentally there to do" (Johnson et al. 2014, 108). According to Certo and Miller (2008), these social missions are intended to address basic and long-standing needs such as providing food, water, shelter, education, and medical services to deprived people. Others understand social missions as the development of "new programs, services, and solutions to specific problems (such as chemical dependency, unwanted pregnancy) and those that address the needs of special populations (such as children with disabilities, caregivers for Alzheimer's patients, veterans)' (Korosec and Berman 2006, 449). In the UK where this study is based, the government has defined charitable purposes into 13 categories in the Charities 
Act 2011 (The Charity Commission 2013). These include the prevention and relief of poverty and other disadvantages, and advancements of 'education', 'religion', 'health and life-saving', 'citizen, community and development', 'art, culture, heritage and science', 'amateur sport', 'human rights and equality', 'environmental protection' and 'animal welfare'.

For the enterprising non-profits in our study, many are registered as charities in the UK which gives them special status in terms of tax and asset management. These organisations are legally required to have a clear charitable purpose, which is encapsulated in their mission statement. For social businesses, their mission is often considered to be more fluid which can be altered without legal ramification. In our two cases, the mission statements of the social businesses focus exclusively on social impact which is consistent with the charitable purposes outlined by the Charities Act 2011. The overriding missions have not altered their mission since their inception. We found that, despite the differences, social enterprises from both groups are equally likely to apply different forms of collective bricolage in their events, and it would appear they are equally prone to mission drift. One other case is defined as a public sector social enterprise, which has missions that are compatible to those outlined in the Charities Act 2011. We found no mission drift within this particular case, with some evidence suggesting that the relation with the public sector does confine their missions. Nevertheless, it is hard to draw conclusions from just a solitary case.

The number of interviewed social enterprises is consistent with Eisenhardt and Graebner (2007), who suggest that the number of cases in a qualitative research should be between 4 and 10, as fewer cases limits the possibility of generalisation, and more cases complicate the analysis. As illustrated in Table 1, the selected social enterprises engage in various social activities that are predominantly locally or regionally based, although some are part of a UK or international-wide network. 
Primary data was collected from social enterprises through semi-structured interviews in order to gain access to information on respondents' experiences and opinions (Saunders, Lewis and Thornhill 2012). An interview guide (King and Horrocks 2010) was developed including general questions about the background and activities of both the interviewee and the social enterprise, and specific questions to recall incidences when the strategy of resource bricolage was adopted. Once some of the activities had been identified, further questions were asked regarding the nature of these activities, partnerships, and the different types of resources that they utilised in order to make them happen. The discussion focused predominantly on the activities that the interviewees had experienced personally, although other activities were sometimes touched upon to provide further context for the discussion. On returning from the fieldwork, the interviewers re-read the transcripts to confirm whether the activities mentioned fulfilled all the criteria of bricolage as stipulated by Baker and Nelson (2005).

The first round of interviews was carried out between January and March, 2015. After analysing the data from the first interview, further rounds of interviews were arranged to collect more information and clarify matters. To identify the second interviewees in a social enterprise, we asked the first interviewees to introduce us to someone in their firm who has related knowledge about the questions of our research. Interviews lasted between 30 and 90 minutes, and were arranged with key personnel at these organisations (see Table 1). Interviews were digitally recorded and then transcribed. Secondary data sources consulted included company websites, newspaper articles, and company brochures and reports, to support and triangulate primary findings (Yin 2012).

\section{Data Analysis}


We embarked on an event-based process analysis (Lok and De Rond 2013), which is a posthoc sequential analysis of events that an organisation has embarked on (Labov and Waletzky 2003; Langley 1999). An event can be the result of single or interconnected activities occurring at a specific time or over a period of time (Buttriss and Wilkinson 2006; Woodside and Wilson 2003). Events can be defined as 'an outcome of human acts or changes caused by nature' (Hedaa and Törnroos 2008, 323) and are useful in defining the starting point of a change process (Hertz 1998), or making change visible (Kamp 2005; Nyström 2009). In this methodological approach, events are used to create a narrative or case history, and construct a case analysis (Makkonen, Aarikka-Stenroos, and Olkkonen 2012; Pettigrew 1997; Polkinghorne 1995). An event-based approach is particularly useful for this study because we are most interested in how each of the events is affected by the participations of different partners, and how each of these events can be seen within the mission and strategic developmental frameworks of the companies.

Following Langley's (1999) advice, multiple strategies for data analysis were combined. As a first step, based on the interviews and documentation, a detailed process of reconstruction of each occurrence of bricolage was made in the form of an event sequence file (Poole et al. 2000). From the interview transcripts, each event of bricolage was identified. We first gathered all the relevant bricolage events from all the cases' narratives (Flanagan 1954; Gladwell 2002; Evers and O'Gorman 2011; Vorley and Rodgers 2013). We then applied multiple coding schemes to categorise different events and activities (Strauss and Corbin 1998). We applied an attribute coding scheme (Saldana 2015) to identify four relevant issues based on our conceptual framework: i) nature of bricolage; ii) resource holding partners' involvement, and, iii) resources utilisation; iv) bricolage outcomes, with each of these issues being subdivided into sub-categories (see Table 2). 
The list of key events is displayed in Table 3. We were interested in not only withincase but also between-case analyses for generalisation purposes (Ayres et al. 2003). Consistent with LeCompte and Schensul (1999), we examined the relation between these resources, personal attributes and attitudes, or any combination of them, and certain actions and behavioural outcomes. Finally, as with Merrill and West (2009), we identified common connections between themes across cases for theory generation.

We extracted from each case between 4 and 13 events in total, giving us a total of 80 events. It is important to note that, consistent with Berends et al. (2014), the events recorded do not represent the full range of activities in which the social enterprise has taken part but, rather, those that the interviewees have personal experience of, and first-hand information about. We also recorded events that are in the pipeline, in which the social enterprise intends to take part in the near future. Some of the key events mentioned in the results are presented in Table 4.

*** Insert Table 3 and Table 4 about here ***

\section{Results}

\section{Internal Bricolage}

\section{No Partner's Involvement and Its Impact on Social Enterprises' Mission}

Our results found that, in their internal bricolage events (with no partner's involvement), social enterprises often adopted an approach whereby pre-existing resources and competencies at hand are being re-utilised through reconfiguration. We termed this approach cost pragmatism. In INT1 (see Table 4), the new mobile hospice project requires almost identical competencies to that of a physical hospice, but with beds in the hospice being in very short supply, the service 
extension provides a service that would otherwise be unattainable and unaffordable. Similarly, in INT2 and INT3, both Consultancy for Social Change and Student Mentoring extend their service provisions from one to one support towards group training in order for more people from their intended market to receive the service at a lower cost. In the event of INT3, for instance, the CEO mentions:

I am now offering parent coaching and parent training sessions based on the resources that I have picked up through my experience of coaching students.... I deliver free workshops for parents. I can see what would be interesting for parents to know, what theories behind that would be good for them... The information and feedback that I got enabled me to test the market and decide whether I can offer the workshop again... All the time I am reusing the knowledge that I have...

The extension of the market onto parents enabled the intended target, i.e. students, to receive better support, thus producing an additional social value for their intended market.

Cost pragmatism appears to have limited the scale and scope of expansion. There is no noted expansion as a result of these internal bricolage activities (e.g., INT1, INT2 and INT3) and the new operations are of relatively small scale to begin with. They can all be considered frugal solutions offering a similar service to part of the same market which could not afford the full price. Only when the offered products/services have proven more popular are they being rolled out incrementally. For instance, in the case of Consultancy for Social Change:

\footnotetext{
When we started (the consultancy service 15 years ago), none of us had ever been doing training before. Within a few weeks of setting up, someone came to us and said, "Do you run workshops?" We had never done that before, but I did not tell him that, we said, "Yeah, of course." We had just never anticipated we would be asked to do training... they liked what we did... Now about $50 \%$ of our work comes out of running workshops....
} 
Nevertheless, despite incremental development and changes in products and services, the events in this category continue to serve their intended targeted segment. The bricolage activities offer a frugal solution (Radjou et al., 2012) to enable those within the target catchment to be served with an affordable alternative.

\section{Collective Bricolage}

\section{Dormant Partners' Involvement and Impact on Social Enterprises’ Mission}

As can be seen in Figure 1, resource holders in this category hold power over the social enterprise but have no integrative involvement in its operation. In the 16 events involving dormant partners, the majority of them are donors (7 events) and for-profit organisation (5 events), who often offer social enterprises financial and resource support, both through direct (5 events) and indirect means (9 events), in enabling them to pursue the social projects that they were hoping to embark on. With the additional resources, social enterprises were more able to pursue 'idealism' rather than making a pragmatic compromise. For instance, Hospice for All embarked upon a new hospice which cost them $£ 16$ million (DOR1), instead of opting for a cheaper alternative that is less well-served by transport. According to its CEO (referring to the DOR1):

\footnotetext{
This is for future generations and will provide care for 50 years, so it's important we get it right... We have talked to people who have built modern hospices, we have talked to our patients... One of the key things that we found out talking to patients and relatives is they want to be somewhere they can still experience life going on and are still part of the local community.
}

Similarly, their children's hospice is consistent with their overarching objective, but with the additional resources from donors, they were able to offer a niche segment specific 
rather than a frugal product, in contrast to the mobile hospice project (INT1) where resource minimisation was intended.

Nevertheless, despite the introduction of new partners, the events that these social enterprises have embarked upon are largely consistent with their organisational missions, whilst we found evidence that with product extension and market expansion, for instance, in DOR2, where Homelessness Support has diverged into offering meals rather than accommodation to homeless individuals, their target recipients remain the same. One reason could be due to the autonomy that these partners are prepared to offer to social enterprises, with one respondent from a social enterprise referring to them as the 'silent partner'. Most of the communications between the social enterprises and their partners involve an 'inform' strategy, where the former disseminate information regarding progress and highlight the benefits that the latter can receive from continuing the relationship. This reflects a transactional relationship between the two parties, with the partner's 'silence' enabling social enterprises to remain focused on how their targeted recipients can be better supported.

With the additional resources, it is evident that social enterprises also tend to adopt a more cautious approach as is presented in some of the events. In DOR1, considerable effort and cost have been involved to plan for both the new hospice and the children's hospices, which include numerous rounds of consultations, design and planning, intended to maximise both economic and social value.

\section{Complementary Partner's Involvement and Impact on Social Enterprises' Mission}

As illustrated in Figure 1, in this relationship two parties have symmetric power and are mutually dependent on each other in a transactional-based relationship. In these events, social enterprises create new social value for their clients by swapping pre-existing, often unused or under-used, slack resources, for access to the partner's facilities with little cost. For instance, 
in COM1, Disadvantaged Youth Support creates new sports and other programmes for their target recipients through obtaining access to a gymnasium owned by a local charity, in return providing it with access to its vehicles and kitchen.

Social enterprises may also work with complementary partners for economic reasons to earn some money and better serve their existing market. In COM3, exchanging donated stocks with a partner increases the stock relevance for both parties and enables them to potentially increase their revenues from the sale of those stocks. Similarly, collective buying and other sharing practices by Hearing Support in COM4 enable both organisations to reduce their running costs. These transactions are largely pragmatic, pre-determined by resource availability from the partner. As they remain largely autonomous from the other's activities, these events also tend to be relatively small scale endeavours involving mostly localised exchange. Nevertheless, cooperation may also go beyond the simplest form of resource swapping, as illustrated by the student competition event by COM2 where Student Social Action held their student enterprise competition in conjunction with the annual conference of a learned association of enterprise educators. Whilst they collaborated in terms of timing and venues, they each ran their own activities. However, by bringing the events together, they were able to tap into each other's clients and create additional activities that would otherwise have been unavailable, thereby maximising the social impact for the corresponding market with little extra cost. It would also make their events look more 'joined-up', and thus attract student and media attention.

Transactional pragmatism offers each party the autonomy to work towards their own agenda and create additional social values for their respective market. One important mechanism to keep such relationships going is the mutual respect that they have for each other. In the 9 events involving complementary partners, the majority of the relationships are between social enterprises of similar nature ( 5 events). The frequent interaction between them enables 
them to develop trust in the other party to allow them access to their own resources and not worry about being exploited. In most events, an informal, ad-hoc approach that does not always have to be strictly fair has been adopted, as providing resources for other social organisations in need is deemed the right thing to do. The informal attitude to exchange is apparent from the ways Disadvantaged Youth Support, for example, cooperates with a partner whilst supporting each other to maintain their common values:

\footnotetext{
We work with a (local) church, a small one. We want to help young people, but we are also Christian based. We send them food parcels. They have a gymnasium. They send people here for hot drinks, chats, etc. They can use our vehicle, we can use theirs. We can both develop our services together.
}

The transactional nature of most of the relationships also means that when one of them feels that they are not making the best of the exchange, it can be terminated. Even in the case of COM2 where two events are being brought together, because the two programmes were not designed to be integrated, they can break off in the future if the partnership is not deemed fruitful to either party.

Our findings indicate that complementary resource holders' involvement does not usually cause mission drift. The social enterprises continue to serve the market they intend to serve, but with new activities that they were unable to offer without the cooperation.

\section{Collaborative Partners' Involvement and Impact on Social Enterprises' Mission}

In collaborative partnerships there is symmetric power among partners but they are very much involved in the event. Within the events that we studied, the collaborative strategy is most commonly applied between two social organisation partners (12 out of 19 events), with the intention to co-create social outcome. All these projects aim to pragmatically utilise the strengths that the other party has on offer. For instance, in COL1, in the resulting joint activities 
a book club only came about because each party happens to possess certain resources (i.e. idle, publicly donated books from the social enterprise, and experienced convenors from the partner) and both partners are happy that these resources are being used collectively. By doing so, such collaboration strengthened their resource base, and they are often able to expand their activities and scope by offering completely new (in 10 out of 19 events) or partially new (in 5 out of 19 events) products to their targeted groups.

Co-creational pragmatism does mean that the social enterprise no longer maintains full autonomy in its events. One key control mechanism is constant negotiation between partners, particularly at the idea shaping stage, towards the eventual outcomes that both organisations desire. For instance:

...the college that I am working with, I met the vice principal and he said, "Er, could you do any teacher training with international students?" And I said, "Yes, how about I do a free focus group where I meet with students and ask them questions to get some ideas about their needs?" We developed training for 60 staff for four hours. We did that in conjunction with them so the training echoes what the students were telling us so we could design it around the needs that the school had (COL5, Student Mentoring).

Nevertheless, rather than seeing such negotiation as burdensome, the co-creation process has also been described by some as an adventurous endeavour. For instance, in COL6 where Student Consultancy ran stress management workshops as part of art and music therapies, with another social enterprise working with people with mental health issues, the founder explains the product as below:

We collaborated and designed the programme together... it is exactly what we both wanted, something different, fun, low cost but informative...

Negotiation, however, does not guarantee that the social enterprise's own objective is being entirely fulfilled. In events where the social objectives of the two involved parties are 
closely aligned with each other (helping homeless people in COL3 and COL4), these joint initiatives could result in the objectives of both parties being fulfilled at the same time. In some other cases, however, goal incongruence can lead to the adoption of a compromised outcome away from their intended mission. We found that 8 out of 19 events can be classified as 'mission drift'. For instance, in COL1, the involvement of a social organisation focusing on reducing social isolation resulted in recipients who are not seen as the target market of Homelessness Support, i.e., those who are socially isolated but not homeless being admitted to the organisation's facilities, and thereby conflicting with their original intention. Similarly, in COL2, whilst the event, an introduction of a new fair-trade product range, provides Empowering Lives Worldwide with an additional source of income, it gives them very little control over how its partner implements the social project on the ground, and therefore little control on the social impact the project created. Nevertheless, although mission drift is present within this group, the social impact that it had on the majority, including the above, is considered to be mild ( 7 out of 19). The above cases, for instance, rely on idle resources (idle donated books in COL1) or existing infrastructure (existing retail outlets in COL2) with few additional costs to the social enterprise.

Within this category, we found the more severe form of mission drift in just one event, COL6, where although Student Mentoring continued to utilise its capacities in stress management, it deviates from its student target group. The main reason is because the partner has a strict target criteria that they do not want to breach. Nevertheless, the social enterprise remains adamantly committed to the partnership. The founder explains the reasons for mission drift and serving a new target group as follows:

The founder (of the social enterprise that Student Mentoring has started to work with) is a friend, a contact for years... it has now turned into something else (a partnership). You never know if this can be grown into something else.... 


\section{Dominant partners' involvement and impact on social enterprises' mission}

In this relationship there is asymmetry of power with integrated involvement of partners. Most events with dominant partners in our study involve the public sector (11 out of 15 events) with the intention of producing a direct and intended social impact on their intended target (13 out of 15 events). In order to do so, the partners either become directly involved in these events, as in DOM1 where the NHS (National Health Service) sent in health professionals to Homelessness Support to implement a health programme for the homeless or, in other events, formally lay out their expectations prior to the commencement of the projects and impose strict conditions to ensure that their goals are being effectively implemented. In most cases, a contract is put in place between the parties. Some of these contracts specify the targeted recipients, for instance, in DOM5, the Prison Service stipulated that the recipients of support must be ex-offenders, or in DOM3 and DOM4 where the local council imposed a 5-year local residential requirement on tenants to ensure that the new accommodation is being used to support the local population. Contracts are also being used to dictate resource usage. For instance, in DOM2, the quantity and quality of the hearing aids produced by Hearing Support are being regulated. In a number of the events that involve the Empty Homes Initiative (EHI), which is a local government initiative to bring derelict buildings back into regular use, the details of how the property should be used is specified in the contract of the local government with the social enterprise.

Evidently, social enterprises that work with a dominant partner often adopt a compliance approach, particularly those not relying on grants or donation support, as suggested by the founder of Consultancy for Social Change:

\footnotetext{
Almost all the produce we get is on a commission basis, so someone's coming to us and saying, "Can you do this?", and require us to design what we are going to do for them... we would often comply.
} 
Compliance is not necessarily a problem when the goals of both parties are largely aligned. For instance, in DOM3, the offer of empty properties by the local government matches well with the desire of Disadvantaged Youth Support to develop accommodation for young people. However, when goal incongruence occurs, social enterprises have to choose whether or not to continue to pursue such relationships. As part of the EHI, Hospice for All, for instance, was offered a rent-free empty property to be used as the hospice. Despite going through the negotiation process, Hospice for All eventually decided not to pursue the partnership because the location of the property was not well-served by public transport which meant accepting the offer would jeopardise the convenience of the people that they intended to serve. However, the lure of additional resources such as those offered by EHI can often induce social enterprises towards pragmatically accepting mission drift. In DOM4, Homelessness Support took up a derelict hotel through the EHI to develop supported accommodation even though it diverged from their original target of the homeless population. Overall, out of the four forms of collective bricolage, the events that involve working with dominant partners have the highest proportion of mission drift events ( 7 out of 15), as well as the greatest variety ( 3 out of 15 ).

Whilst the above suggests that working with a dominant partner can increase susceptibility to mission drift, relational pragmatism can, on the other hand, discourage further product and market development. For instance, Hearing Support relies almost exclusively on contract income from the NHS (see DOM2), and felt they had little room to divert from the funder's expectation. This resulted in them not introducing new products or attracting new clients. It is also felt by others that contractual relationships with government bodies can increase dependency, and force them not to consider innovation opportunities and alternative strategies that would benefit their intended target market socially. Some also fear that the dependency relationship may hinder their long term competitiveness, especially when they are 
facing challenges from private providers who, seeing the possible benefit to them, are gradually entering the market.

Although 'compliance' strategy seems to be the dominant approach, some social enterprises within our study also found that a 'persuasion' strategy works in their favour. Consultancy for Social Change illustrates that a social enterprise can also influence funders and co-create the activity undertaken:

\begin{abstract}
A few years ago [a local] council came to us and said, "We've got European funding to support forty community groups, and we would like your help to run a workshop on sustainability." We said, "That's ridiculous, one workshop is not going to make them sustainable," and we suggested that we have a session with the community groups... and we talked about what the needs and requirements were, and we had this big list, and we went back to the council and said, "Look, this is what they need help in, and we can help you deliver this, and this is how we suggest you to do it"....and they said, "Yup, okay, that sounds good to us, let's do that."
\end{abstract}

\title{
Discussion
}

A summary of the findings of this research is presented in Table 5.

$$
\text { *** Insert Table } 5 \text { about here*** }
$$

A number of areas of common ground can be found between events of social enterprises utilising internal and collective bricolage. Both improvise with their situation in utilising resources and competencies at hand to create new activities. The resources that these social enterprises acquired for each event then allowed them to branch out into new activities. These findings are broadly consistent with the existing literature on bricolage in for-profit and social enterprises (Baker and Nelson 2005; Di Domenico, Haugh and Tracey 2010).

We also found notable differences. First, our findings suggest that resource constraints led to major differences between events utilising internal and collective bricolage. Events that 
involved internal bricolages deployed a pragmatic approach utilising only pre-existing resources and competencies internally available. Such an approach is akin to the parallel bricolage in Baker and Nelson (2005), and as previous studies suggest, tends to be small in scale with the changes in product and market likely to be logically incremental compared to the previous mission of the social enterprise. In contrast, collective bricolage can be seen as a form of peer-production (Bauwen 2005). When engaging in collective bricolage, events can be larger in scale and the bricolage outcomes (change in product/market) can sometimes be drastically different from their previous focus. This is consistent with the idea of selective bricolage which suggests that, with additional resources, organisations can break away from their mutually reinforcing resource dependency and pursue largely and often more innovatively ground-breaking ideas, which, according to some such as Baker and Nelson, (2005) and Senyard et al. (2014), offers them a strong competitive advantage over their competitors, leading to superior performance outcomes. In doing so, collective bricolage not only benefits each party individually, but also contributes to the social and solidarity economy as a whole.

However, we found that, despite the availability of additional resources, few collective bricolage events were able to fully pursue an idealistic bricolage outcome. Our findings show that the ability to pursue idealism is determined by two factors: whether a social enterprise is asymmetrically dependent on the partner's resources and competencies, and whether the involvement of the partner in the project is integrative. It is only when the collective bricolage involves a dormant partner, whose involvement is transactional and does not expect a reciprocal relationship, that a social enterprise can fully enjoy the autonomy to execute the usage of the additional resources for the mission that it aims for.

Pragmatism dictates other collective bricolage events. Working with complementary resource holders is similar to Bauwens' (2005) notion of peer-production that he observed amongst some of the peer-to-peer initiatives. In these events, each partner devotes significant 
resources to the pool where its content is then made universally available for other social enterprises to explore. Their interests remain diverse which is likely to work particularly well between non-rival partners or on anti-rival goods. Although their transactional involvement also offers a similar level of autonomy as those working with dormant partners, the separation of resource pools results in social enterprises pragmatically accepting a smaller resource base to operate on which hinders their growth potential.

Events involving a collaborative partner often involved mutual adaptation with the eventual co-produced outcome being the converged collective interest reflecting the common values shared by the parties involved. Although the pooling of resources has provided the scope to expand, we found that the integrative involvement of their partner has resulted in the social enterprises pragmatically accepting the loss of some level of autonomy through the co-creation process. With co-creation now being a common property, Ostrom's (1990) concern for regulation and governance is particularly relevant. We observed that, unlike working with complementary resource holders, such arrangement places less emphasis on mutual respect, but more on regulation. In most of our events, regulation is through extensive negotiation prior to partnership as well as through the continuing involvements of the different parties into the co-created outcomes.

Finally, in the events where a dominant partner is involved, social enterprises often need to pragmatically accept a significant loss of autonomy to the partner whose resources they are asymmetrically dependent on, but are themselves very keen to keep a close eye on the execution of the project to ensure their own objectives are being fulfilled.

Our study finds that social enterprises engaging with different partners in their bricolage events can impact on how the resulting bricolage outcomes will differ from their original mission. In addition to internal bricolage, collective bricolage involving dormant and 
complementary partners allows social enterprises to maintain independence while remaining loyal to their targeted recipient. On the other hand, combining additional resource availability and the lack of autonomy sometimes means that social enterprises involving collaborative and dominant partners are no longer able to fully control their bricolage events, resulting in a drift in their social mission. This suggests that mission drift not only depends on the traits and characteristics of the social enterprises and the social entrepreneurs as previously suggested (Perrini et al. 2010), but also the resource dependence relationship that they had with their partners and the nature of their partner's involvements. We found that most events of mission drift came from working with a dominant partner. In such events, managing a relationship with them often involves 'relational pragmatism' whereby their own social impact has been compromised, with the strategy of 'compliance' being most widely adopted to ensure a good relationship with the partner and thereby securing a long term resource dependency relationship, as suggested in prior studies. Social enterprises involving collaborative partners may also be susceptible to mission drift to a lesser extent, as although collaborative efforts often intend to co-create social impact, the pragmatic need to negotiate and make compromises may mean that the co-created event can fall short of either parties' ideal.

The mission drift that we found in our study can be divided into three categories. First, we identify a form of mission drift whereby the co-production process resulted in social enterprises refining their missions towards the co-created social objective(s). In partnerships where the mission itself is determined through a democratic process, the change in mission reflects the collective, need-based consensus towards a new mission that is desired by all parties concerned. From the social and solidarity economy's perspective, such refinement reflects the efficient use of resources and is thus by no means undesirable. Furthermore, although the social enterprises engaging in such a partnership may have to sacrifice some of their ability to serve the target group originally intended, the higher joint social impact would potentially 'trickle- 
down' to such a group, resulting in them being better-off than without such a partnership. COL1 is a prime example whereby homeless people, the intended target group of Homelessness Support, were able to benefit from the new initiative offered by the collaborative partnership with an expanded target catchment.

We also found a second form of mission drift which we termed 'frugal' drift, which is the practice of avoiding wastage by giving away idle or unwanted resources to create new social impact in other social organisations, over which the social enterprise has no control. Essentially the social enterprises themselves become the dormant partner of the other social organisation. Such drifts tend to be unintentional and without prior planning, but would not be considered detrimental to the social enterprise's own mission. In the light of our findings in relation to the above two forms of mission drifts, we challenge the conventional view that mission drift should inherently be viewed as negative. We argue that, in some circumstances, the benefits of mission drift could potentially outweigh the mis-targeting problem that they created. Consistent with O'Reilly III and Tushman (2011), missions should continue to evolve and new ones could emerge when new needs arise. Such changes could potentially result in more efficient ways of creating social impact being delivered.

The challenge of mission drift only arises when social enterprises embark upon change for the sake of commercial profitability. We identify the third type of mission drift as 'financialpull', where drift is driven intentionally by the desire to improve financial viability (Jones 2007). The potential danger is that social enterprises may be at risk of displacing their previous goals. For instance, in explaining her contemplation on engaging in managerial coaching for for-profit companies, the founder of Student Mentoring explains that:

The social enterprise is set up so that it does not rely on funding but sales... (Although) my commitment to what I am doing is extremely high, I cannot run for nothing... I am reusing the 
performance coaching in a different (for-profit) setting and, if it works, I can start to focus on the holiday period when it goes quiet for students.

With regard to the third type of mission drift, another danger is the risk of losing legitimacy (Dart 2004). As some of them ventured into commercial opportunities, private companies may successfully enter into the market and drive them out of the market, and to make the problem worse, they may lose the option to return to their previous operating agenda, as they lose legitimacy to do so (Young and Salamon 2002; Coston 1998). On the other hand, we also came across events where social enterprises rejected the opportunity to work with resource holders, a decision not without financial consequences. We also found that those involving dominant resource holders can be a double-edged sword, which in the case of goal incongruence, led to mission drift and prevented them from making any changes towards new objectives that may have been considered necessary.

Overwhelmingly, mission drift identified within our collective bricolage events is of the first and the second type, and is considered to be mild. However, although we found few incidents of significant mission drift with events engaging dormant, complementary partners, we found some evidence that continued collaboration can sometimes lead to further mission drift in future events. For instance, the collaboration between Student Mentoring and a forprofit organisation results in the former seriously contemplating the offering of a performance coaching service to the for-profit business, particularly during the summer season when the number of students is low, to supplement its income to ensure sustainability. This risks opening a floodgate, moving further towards for-profit business without any social orientation. Furthermore, increasing commitment to the number of events could mean that social enterprises and their partners becoming increasingly interdependent on others' resources, and in doing so form a reliance chain that cannot easily be broken away from.

\section{Conclusion}


In this research we explored the impact of bricolage and collaboration on changes in the mission of social enterprises. Our findings indicate that collective bricolage can often result in the expansion of products for the existing customers, thus enhancing the social impact created. However, we also found incidents whereby social enterprises expand their market by serving a clientele that was not initially defined as part of their mission, as well as cases whereby the original target that the social enterprises initially intended to serve was no longer being served by the product that they offer.

This research offers several theoretical contributions. First, it extends the boundaries of bricolage and RDT theory to the context of social enterprises, as suggested by prior studies (Desa 2012; Desa and Basu 2013; Di Domenico, Haugh, and Tracey 2010). It also contributes to social entrepreneurship literature by providing new insights about bricolage, collaboration and the potential impact that it might have on the pursuit of social enterprises' missions. Methodologically, we categorise partners according to the distribution of power and the nature of the relationship with the social enterprise, rather than their type. We believe that such an emphasis provides us with a much clearer perspective on how different relationships that social enterprises have with their resource holders affect the outcome of bricolage. Second, our paper offers a critique of the limitations of looking at social enterprise through the lens of 'missions' and 'transaction-cost' economics. We argue that, in additional to adapting to external change in context, missions should be fluid enough to respond also to changes in internal dynamics, in order to effectively utilize the resources and expertise the different partners can offer and, in doing so, maximize their potential to bring about socio-economic transformation. Third, our findings contribute to the literature on social and solidarity economy (Fonteneau et al. 2011), particularly on how resources under social enterprises' private controls can be transferred to the commons through collective bricolage in collaborative and complementary partnerships. Collaborative partnership, in particular, offers social enterprises the chance to embed 
themselves in the social and solidarity economy at large rather than being driven purely by their narrow institutional focus. Given the sample of the study features mostly enterprising nonprofit and social businesses, our findings indicate that it is not only social cooperatives which can contribute to the social and solidarity economy.

Besides the theoretical contributions that we highlighted in the discussion section, our study also has a number of managerial and policy implications. For managers, understanding ways in which the origin of resources may have an impact on the scope of their mission would ensure a realistic expectation of what they can achieve subject to resource constraints. It would also help them to understand how working with resource holders with symmetric/asymmetric power and the level of integration with them can potentially impact their mission. Therefore, our findings will enable the managers of social enterprises to think more carefully and strategically before entering into partnerships or collaborative arrangements. Whilst additional resources can often enable social enterprises to expand and reach new markets, not all partnerships would ensure that the social concern of social enterprises was being better served. We further argue that the understanding of collaborative and complementary partnerships offers managers of social enterprises a much more enriched insights into the advantages of fully participating in the social and solidarity economy. Our findings indicate that to work towards the greater good of societies does not always require social enterprises to sacrifice their own interests, but the co-creation could potentially further enrich, not diminish, the experience of those they intend to support.

Our research also has implications for policy makers. Policy makers can play a pivotal role in facilitating the occurrence of bricolage activities. An area where policy makers can help is in supporting social enterprises to become better connected. A brokerage system or the regular organisation of social and networking events between social enterprises, government agencies, and relevant for-profit organisations would enable social enterprises to be better 
connected and enhance their ability to produce transformative changes. A coherent agenda towards a social and solidarity economy could also be outlined by policy makers to ensure that such vision can be pragmatically implemented.

In terms of future research direction, a number of extensions can be made to this study that would enhance our understanding of collaboration and bricolage within social enterprises. First, organisational cases in this research were limited to those that we have connections with. Future studies can build on the findings of this research and test the generalisability of our findings in a larger, randomly selected population. Second, the findings are limited to social enterprises in the UK which are affected by the particular institutional and cultural framework of the country. Further studies on other countries, particularly developing country contexts with a much more penurious environment, would enhance our understanding of the role of collaboration and bricolage in the growth of product and market scope. Finally, future study is advised to adopt a longitudinal approach in order to better capture the changes occurring within social enterprises. 


\section{References}

Alter, C. and J. Hage. 1993. Organizations Working Together. Newbury Park, CA: Sage Publications.

Austin, J. E. 2000. "Strategic collaboration between nonprofits and business". Nonprofit and Voluntary Sector Quarterly 29(s1): 69-97.

Ayres, L., K. Kavanaugh and K. Knafl, 2003. "Within-case and across-case approaches to qualitative data analysis". Qualitative Health Research13(6): 871-883.

Baker, T., A. Miner, and D. Easley. 2003. "Improvising firms: bricolage, account giving and improvisational competencies in the founding process. " Research Policy 32 (2):255-285

Baker, T., and R. Nelson. 2005. "Creating something from nothing: Resource construction through entrepreneurial bricolage." Administrative Science Quarterly 50 (3):329-366.

Balser, D., and J. McCluskey. 2005. "Managing stakeholder relationships and nonprofit organization effectiveness". Nonprofit Management and Leadership15(3): 295-315.

Barney, J. 1991. "Firm resources and sustained competitive advantage." Journal of Management 17 (1):99-120.

Basu, S. and G. Desa. 2014. "Responding to Market Failures: The Role of Business Models in Social Entrepreneurship." Academy of Management Proceedings 2014(1): 17338-17338.

Bauwens, M., 2005. “The political economy of peer production”. CTheory, 12-1.

Berends, H., M. Jelinek, I. Reymen, and R. Stultiëns. 2014. "Product innovation processes in small firms: Combining entrepreneurial effectuation and managerial causation". Journal of Product Innovation Management 31(3): 616-635. 
Brinkerhoff, J. M., 2002. “Government-nonprofit partnership: a defining framework”. Public Administration and Development 22(1): 19-30.

Brooks, A. C. (2009). Social Entrepreneurship: A Modern Approach to Social Value Creation. Upper Saddle River, NJ: Pearson.

Buttriss, G., and I. Wilkinson. 2006. "Using narrative sequence methods to advance international entrepreneurship theory." Journal of International Entrepreneurship 4 (4):157174. doi: 10.1007/s10843-007-0012-4.

Certo, S.T. and Miller, T., 2008. "Social entrepreneurship: Key issues and concepts.” Business Horizons 51(4): 267-271.

Coston, J. M. 1998. "A model and typology of government-NGO relationships". Nonprofit and Voluntary Sector Quarterly 27(3): 358-382.

Chalmers, D. M., and E. Balan-Vnuk. 2013. "Innovating not-for-profit social ventures: exploring the microfoundations of internal and external absorptive capacity routines." International Small Business Journal 31(7): 785-810.

Dart, R., 2004. "Being "business-like" in a nonprofit organization: A grounded and inductive typology". Nonprofit and Voluntary Sector Quarterly 33(2): 290-310.

Defourny, J. and M. Nyssens. 2016 "Fundamentals for an International Typology of Social Enterprise Models", ICSEM Working Papers, No. 33.

Desa, G. 2012. "Resource mobilization in international social entrepreneurship: Bricolage as a mechanism of institutional transformation." Entrepreneurship: Theory and Practice 36 (4):727-751. doi: 10.1111/j.1540-6520.2010.00430.x. 
Desa, G, and S. Basu. 2013. "Optimization or bricolage? Overcoming resource constraints in global social entrepreneurship." Strategic Entrepreneurship Journal 7(1):26-49.

Dey, P. and C. Steyaert 2012. Critical reflections on social entrepreneurship. In Social Entrepreneurship and Social Business (pp. 255-275). Springer: Gabler Verlag.

Di Domenico, M., H. Haugh, and P. Tracey. 2010. "Social Bricolage: Theorizing Social Value Creation in Social Enterprises." Entrepreneurship: Theory and Practice 34 (4):681-703.

DTI 2003. Enterprise for Communities: Report on the Public Consultation and the Government's Intentions, HM Treasury: London.

Duymedjian, R. and C. Rüling. 2010. "Towards a foundation of bricolage in organization and management theory". Organization Studies 31(2): 133-151.

Ebrahim, A., 2002. "Information struggles: The role of information in the reproduction of NGO-funder relationships”. Nonprofit and Voluntary Sector Quarterly 31(1): 84-114.

Eisenhardt, K.M. and M. E. Graebner. 2007. "Theory building from cases: Opportunities and challenges". Academy of Management Journal 50(1): 25-45.

Etzioni, A., 1975. Comparative Analysis of Complex Organizations, Rev. Simon and Schuster: NY

Evers, N. and C. O'Gorman. 2011. "Improvised internationalization in new ventures: The role of prior knowledge and networks". Entrepreneurship and Regional Development 23(7-8): 549574.

Fisher, G., 2012. "Effectuation, causation, and bricolage: a behavioral comparison of emerging theories in entrepreneurship research". Entrepreneurship Theory and Practice 36(5): 10191051. 
Flanagan, J.C., 1954. "The critical incident technique”. Psychological Bulletin 51(4): 327.

Fonteneau, B., N. Neamtan, F. Wanyama, L. Morais, M. de Poorter, C. Borzaga, G. Galera, T. Fox and N. Ojong, 2011. Social and Solidarity Economy: Our Common Road Towards Decent Work. International Labour Organization: Geneva.

Foster, M.K. and A. Meinhard. 2002. "A regression model explaining predisposition to collaborate". Nonprofit and Voluntary Sector Quarterly 31(4): 549-564.

Frooman, J. 1999. "Stakeholder influence strategies". Academy of Management Review 24(2): 191-205.

Garud, R. and P. Karnøe. 2003. "Bricolage versus breakthrough: Distributed and embedded agency in technology entrepreneurship." Research Policy 32(2):277-300.

Garud, R., A. Kumaraswamy and P. Karnøe, 2010. "Path dependence or path creation?" Journal of Management Studies 47(4): 760-774.

Ghauri, P. N., M. Tasavori, and R. Zaefarian. 2014. "Internationalisation of service firms through corporate social entrepreneurship and networking." International Marketing Review $31(6): 576-600$.

Gladwell, M. 2002. The Tipping Point: How Little Things Can Make a Big Difference. New York: Little Brown and Company.

Grimes, M. and B. Victor. 2009. "Development and validation of empirical measures for social entrepreneurship". Academy of Management Annual Meeting. Chicago, Sept 15.

Graebner, M.E., J. Martin and P. Roundy. 2012. "Qualitative data: Cooking without a recipe”. Strategic Organization 10(3): 276-284. 
Halme, M., S. Lindeman and P. Linna, 2012. "Innovation for inclusive business: Intrapreneurial bricolage in multinational corporations". Journal of Management Studies 49(4): 743-784.

Harbaugh, W.T., 1998. "The prestige motive for making charitable transfers". The American Economic Review 88(2): 277-282.

Hardin, G., 1968. The Tragedy of the Commons, Science, 162, 1243-1248.

Hedaa, L. and J. Törnroos. 2008. "Understanding event-based business networks." Time and Society 17 (2-3):319-348. doi: 10.1177/0961463X08093427.

Hertz, S. 1998. "Domino effects in international networks." Journal of Business-to-Business Marketing 5 (3):3-22

Hill, C.W. and T.M. Jones, 1992. "Stakeholder-agency theory". Journal of Management Studies 29(2): 131-154.

Huybrechts, B. and Nicholls, A., 2013. "The role of legitimacy in social enterprise-corporate collaboration". Social Enterprise Journal 9(2): 130-146.

Jaffee, David. 2001. Organization Theory, Tension and Change. New York: McGraw-Hill.

Johnson, G., R. Whittington, and K. Scholes, D. Angwin and P. Regner. 2014. Exploring Strategy. Pearson: London

Jones, M. B. 2007. "The multiple sources of mission drift". Nonprofit and Voluntary Sector Quarterly 36(2): 299-307.

Jayawarna, D., O. Jones, and A. Macpherson, 2014. "Entrepreneurial potential: The role of human and cultural capitals". International Small Business Journal 32(8): 918-943. 
Kaine, S. and J. Green. 2013. "Outing the silent partner: Espousing the economic values that operate in not-for-profit organizations". Journal of Business Ethics 118(1): 215-225.

Kamp, B. 2005. "Formation and evolution of buyer-supplier relationships: Conceiving dynamism in actor composition of business networks." Industrial Marketing Management 34 (7):658-668. doi: 10.1016/j.indmarman.2005.04.006.

Korosec, R.L. and Berman, E.M., 2006. "Municipal support for social entrepreneurship." Public Administration Review 66(3): 448-462.

King, N. and C. Horrocks, 2010. Interviews in Qualitative Research. Sage: London Labov, W. and J. Waletzky. (2003) "Narrative analysis: Oral versions of personal experience." By W. Labov and J. Walezky (eds) Sociolinguistics: The Essential Readings. 74-104.

Lanzara, G. F. 1998. "Self-destructive processes in institution building and some modest countervailing mechanisms." European Journal of Political Research 33: 1-39.

Lanzara, G. F. 1999. "Between transient constructs and persistent structures: Designing systems in action." Journal of Strategic Information Systems 8(4): 331-349.

Lanzara, G.F. and G. Patriotta, 2001. "Technology and the courtroom: An inquiry into knowledge making in organizations". Journal of Management Studies 38(7): 943-971.

Langley, A. 1999. "Strategies for theorizing from process data". Academy of Management Review 24(4): 691-710.

Lepoutre, J., R. Justo, S. Terjesen and N. Bosma, 2013. "Designing a global standardized methodology for measuring social entrepreneurship activity: the Global Entrepreneurship Monitor social entrepreneurship study”. Small Business Economics 40(3):693-714.

Levi-Strauss, C. 1967. The Savage Mind. Chicago: University of Chicago Press. 
Lok, J. and De Rond, M., 2013. "On the plasticity of institutions: Containing and restoring practice breakdowns at the Cambridge University Boat Club." Academy of Management Journal 56(1): 185-207.

Makkonen, H., L. Aarikka-Stenroos, and R. Olkkonen. 2012. "Narrative approach in business network process research — Implications for theory and methodology”. Industrial Marketing Management 41(2):287-299. doi: 10.1016/j.indmarman.2012.01.012.

Meegan, R., P. Kennett, G. Jones and J. Croft. 2016. "Global economic crisis, austerity and neoliberal urban governance in England". Cambridge Journal of Regions, Economy and Society 9(3): 1-17

Merrill, B. and L. West. 2009. Using Biographical Methods in Social Research. Sage: London Mitchell, R., B. Agle, and D. Wood. 1997. "Toward a theory of stakeholder identification and salience: Defining the principle of who and what really counts". Academy of Management Review 22(4): 853-886.

Moorman, C. and Miner, A., 1998. "Organizational improvisation and organizational memory". Academy of Management Review, 23(4), 698-723.

Nyström, A. 2009. "Emerging Business Networks as a Result of Technological Convergence." Journal of Business Market Management 3 (4):239-260.

Olson, M. (1965) The Logic of Collective Action: Public Goods and the Theory of Groups. Cambridge: Mass.

Ostrom, E. 1990. Governing the Commons: The Evolution of Institutions for Collective Action: Cambridge University Press: Cambridge. ISBN 0-521-40599-8. 
O'Reilly, C.A. and M. Tushman, 2011. “Organizational ambidexterity in action: How managers explore and exploit”. California Management Review 53(4): 5-22.

Parker, R. and G. Fedder, 2016. "Aircraft engines: a proud heritage and an exciting future." The Aeronautical Journal 120(1223): 131-169.

Penrose, E. T. 1959. The Theory of the Growth of the Firm, Oxford: Oxford University Press

Pettigrew, A. M. 1997. "What is a processual analysis?" Scandinavian Journal of Management 13(4):337-348.

Pfeffer, J., and G. Salancik. 1978. The External Control of Organizations. New York: Harper and Row

Pfeffer, J. and G. Salancik. 2003. The External Control of Organizations: A Resource Dependence Perspective. Stanford University Press: Stanford, CA.

Polkinghorne, D. E. 1995. "Narrative configuration in qualitative analysis." Hatch A and Wisniewski (Eds) In Life history and narrative, 5-24. London: Falmer Press.

Poole, M., A. Van de Ven, K. Dooley, and M. Holmes. 2000. Organizational change and innovation processes: Theory and methods for research. Oxford: Oxford University Press.

Perrini, F., C. Vurro and L. Costanzo. 2010. "A process-based view of social entrepreneurship: From opportunity identification to scaling-up social change in the case of San Patrignano". Entrepreneurship and Regional Development 22(6): 515-534.

Radjou, N., J. Prabhu and S. Ahuja. 2012. Jugaad Innovation: Think Frugal, be Flexible, Generate Breakthrough Growth. John Wiley and Sons: London 
Ridley-Duff, R., (2012). New frontiers in democratic self-management. The Co-operative Model in Practice., in McDonnell, D. and E. MacKnight, (eds.) The Co-operative Model in Practice. Glasgow, Co-operative Education Trust Scotland, 99-118.

Ridley-Duff, R. 2015. The Case for FairShares: an approach to social enterprise development and the strengthening of the social and solidarity economy. Accessed from: http://shura.shu.ac.uk/10198/. Accessed on: 17 November 2015.

Ridley-Duff, R. and M. Bull. 2015. Understanding social enterprise: Theory and practice. Sage: London.

Salancik, G.R. and J. Pfeffer. 1974. "The bases and use of power in organizational decision making: The case of a university". Administrative Science Quarterly 19(4): 453-473.

Saldaña, J., 2015. The Coding Manual for Qualitative Researchers: Sage: London.

Saunders, M., P. Lewis and A. Thornhill. 2009. "Understanding research philosophies and approaches". In M. Saunders (ed) Research Methods for Business Students. Pearson: London. 106-135.

Scott, P., 1995. "Birth of the jet engine". Mechanical Engineering, 117(1): 66-78

Seitanidi, M., D. Koufopoulos and P. Palmer., 2010. "Partnership formation for change: Indicators for transformative potential in cross sector social partnerships". Journal of Business Ethics 94(1): 139-161.

Senyard, J., T. Baker, P. Steffens and P. Davidsson. 2014. "Bricolage as a path to innovativeness for resource-constrained new firms." Journal of Product Innovation Management 31(2): 211-230. 
Sharfman, M.P., B. Gray and A. Yan. 1991. "The context of interorganizational collaboration in the garment industry: An institutional perspective". The Journal of Applied Behavioral Science 27(2): 181-208.

Shaw, E. and A. de Bruin. 2013. "Reconsidering capitalism: the promise of social innovation and social entrepreneurship?”. International Small Business Journal 31(7): 737-746.

Smith, B.R., M. Cronley and T. Barr. 2012. "Funding implications of social enterprise: The role of mission consistency, entrepreneurial competence, and attitude toward social enterprise on donor behaviour". Journal of Public Policy \& Marketing 31(1): 142-157.

Stinchfield, B., R. Nelson, and M. Wood. 2013. "Learning From Levi-Strauss' Legacy: Art, Craft, Engineering, Bricolage, and Brokerage in Entrepreneurship." Entrepreneurship: Theory and Practice 37 (4):889-921. doi: 10.1111/j.1540-6520.2012.00523.x.

Strauss, A. and J. Corbin. 1998. Basics of qualitative research: Procedures and techniques for developing grounded theory. Sage: Thousand Oaks, CA

Sydow, J., G. Schreyögg and J. Koch. 2009. "Organizational path dependence: Opening the black box". Academy of Management Review 34(4): 689-709.

Tasavori, M. C. Kwong and S. Pruthi. 2016. "Resource bricolage and growth of product and market scope in social enterprises". Paper presented at the Academy of International Business Conference, New Orleans, July 2016.

Tasavori, M., P. Ghauri, and R. Zaefarian. 2014. "Entry of multinational companies to the base of the pyramid: Network Perspective." In C. Jones and Y. Temouri (eds) International Business, Institutions and Performance after the Financial Crisis, 39-52. London, UK: Palgrave Macmillan. 
Tasavori, M., P. Ghauri, and R. Zaefarian. 2016. "Entering the base of the pyramid market in India: A corporate social entrepreneurship perspective." International Marketing Review 33 (4):555-57.

Tasavori, M., R. Zaefarian, and P. Ghauri. 2015. "The creation view of opportunities at the base of the pyramid." Entrepreneurship and Regional Development 27 (1/2):106-126.

The Charity Commission. 2013. About Charitable Purposes. Access from: https://www.gov.uk/government/publications/charitable-purposes/charitable-purposes. Accessed 25 Nov 2016.

Teece, D.J., Pisano, G. and Shuen, A., 1997. "Dynamic capabilities and strategic management." Strategic Management Journal 18(7): 509-533.

Utting, P. 2013. What is Social and Solidarity Economy and why does it matter? Oxfam, accessed from: https://oxfamblogs.org/fp2p/beyond-the-fringe-realizing-the-potential-ofsocial-and-solidarity-economy/, accessed 17 November 2016

Vorley, T. and P. Rodgers. 2013. "Home is where the business is: Incidents in everyday life and the formation of home-based businesses". International Small Business Journal doi: $10.1177 / 0266242612452173$.

Weick, K.E., 1998. "Introductory essay-Improvisation as a mindset for organizational analysis." Organization Science 9(5): 543-555.

Weisbrod, B. A. 1997. "The future of the nonprofit sector: Its entwining with private enterprise and government". Journal of Policy Analysis and Management 16(4): 541-555.

Weisbrod, B. A. 1998. The nonprofit mission and its financing: Growing links between nonprofits and the rest of the economy. In Weisbrod and Arrow (ed) To profit or not to profit: 
The commercial transformation of the nonprofit sector, 1-22. Cambridge University Press: Cambridge

Weisbrod, B.A., 2004. “The pitfalls of profits.” Stanford Social Innovation Review 2(3): 4047.

Williamson, O.E., 1973. “Markets and Hierarchies”. American Economic Review, 63(2): 316325.

Woodside, A. G., and E. Wilson. 2003. "Case Study research method for theory building." Journal of Business and Industrial Marketing 18(6/7):493-508. doi: $10.1108 / 08858620310492374$.

Yin, R.K., 2012. Case Study Methods. Sage: London

Young, D.R. and L. Salamon, 2002. Commercialization, social ventures, and for-profit competition, in Salmon, L. (ed) The State of Nonprofit America, 423-446 Brookings Institution Press: Washington, D.C.

Zahra, S.A., E. Gedajlovic, D. Neubaum and J. Shulman, 2009. "A typology of social entrepreneurs: Motives, search processes and ethical challenges". Journal of Business Venturing 24(5): 519-532. 
Table 1. Summary details of the cases

\begin{tabular}{|c|c|c|c|c|c|c|c|}
\hline & Name* & Description of activities & Est. & Region & $\begin{array}{l}\text { ICSEM } * * \\
\text { definition }\end{array}$ & interview & Interviewees' role \\
\hline 1. & Hospice for All & $\begin{array}{l}\text { Supports families and cares for patients (children and adults) } \\
\text { with life-limiting and/or life-threatening conditions. }\end{array}$ & 1983 & East & ENP & 2 & $\begin{array}{l}\text { CEO and Director of Fundraising } \\
\text { and Marketing }\end{array}$ \\
\hline 2. & $\begin{array}{l}\text { Consultancy for } \\
\text { Social Change }\end{array}$ & $\begin{array}{l}\text { Offers a range of expertise and experience in financial, } \\
\text { managerial and technical fields to support organisations } \\
\text { promoting social change across the UK and worldwide. }\end{array}$ & 2002 & $\begin{array}{l}\text { London+ } \\
\text { Int'l }\end{array}$ & SB & 2 & Founder and CEO \\
\hline 3. & Hearing Support & $\begin{array}{l}\text { Takes referrals for hearing tests for adults and children and } \\
\text { discusses the results and offers solutions. }\end{array}$ & 2011 & Midlands & PSE & 2 & $\begin{array}{l}\text { Founder and managing director, } \\
\text { audiologist }\end{array}$ \\
\hline 4. & Health Research & $\begin{array}{l}\text { Conducts research to discover vital treatments and to fight } \\
\text { against diseases. }\end{array}$ & $1980 \mathrm{~s}$ & $\begin{array}{l}\text { East }+ \text { UK } \\
\text { network }\end{array}$ & ENP & 3 & $\begin{array}{l}\text { System manager, outlet manager, } \\
\text { warehouse manager }\end{array}$ \\
\hline 5. & $\begin{array}{l}\text { Empowering Lives } \\
\text { Worldwide }\end{array}$ & $\begin{array}{l}\text { Helps disadvantaged people to improve their lives and } \\
\text { livelihoods and have a say in decisions that affect them. }\end{array}$ & $1970 \mathrm{~s}$ & $\begin{array}{l}\text { East }+ \\
\text { Int'l } \\
\text { network }\end{array}$ & ENP & 2 & Outlet manager \\
\hline 6. & Student Mentoring & $\begin{array}{l}\text { Offers professional performance coaching and mentoring } \\
\text { services to students, helping them to perform better in their } \\
\text { studies and lives. }\end{array}$ & 2013 & East & SB & 1 & Founder and CEO \\
\hline 7. & $\begin{array}{l}\text { Homelessness } \\
\text { Support }\end{array}$ & $\begin{array}{l}\text { Supports homeless people with a range of services including } \\
\text { free food, laundry, showers, housing and benefits advice, } \\
\text { sleeping bags and flasks, advice on finding/keeping } \\
\text { accommodation, etc. }\end{array}$ & 1987 & East & ENP & 1 & Centre manager \\
\hline 8 & $\begin{array}{l}\text { Disadvantaged Youth } \\
\text { Support }\end{array}$ & $\begin{array}{l}\text { Supports young people and children who may be experiencing } \\
\text { homelessness, domestic violence, abuse, poverty, } \\
\text { unemployment or mental health problems, etc. }\end{array}$ & 1995 & $\begin{array}{l}\text { East }+ \text { int' } \\
\text { network }\end{array}$ & ENP & 1 & Centre manager \\
\hline
\end{tabular}




\begin{tabular}{|c|c|c|c|c|c|c|c|}
\hline 9. & Student Social Action & $\begin{array}{l}\text { Connects businesses, academics and students to make a } \\
\text { difference in their communities by using the power of } \\
\text { entrepreneurial action to transform lives. }\end{array}$ & 2001 & $\begin{array}{l}\text { UK + int' } \\
\text { network }\end{array}$ & ENP & 1 & $\mathrm{CEO}$ \\
\hline
\end{tabular}

*not real names

** $\mathrm{ENP}=$ entrepreneurial non-profit model, $\mathrm{SC}=$ social cooperative model, $\mathrm{SB}=$ social business model, $\mathrm{PSE}=$ public-sector social enterprise model 


\section{Table 2. Thematic categories for the event-based analysis}

1) Event categorical information

a. Organisation

2) Nature of the event

a. Description of the event

3) Resource holders' involvement in the event

a. Types of resource holders (none, other social enterprises, for profit organisations, donors, volunteers, government bodies)

b. Main forms of collaboration with the resource holders (internal, dormant, complimentary, collaborative, dominant)

4) Resources utilised in the event

a. Pre-existing resources (Finance, land, physical, human capital, others)

b. Newly acquired resources (Finance, land, physical, human capital, others)

5) Bricolage outcomes of the event (Changes in the mission of social enterprise)

a. New product development (New, extend, existing)

b. New market development (New, expand, existing)

c. Extent of mission $\operatorname{drift}^{1}$ (Severe, mild, minimal)

${ }^{1}$ Mild mission drift is defined as missions that drift away from their original objective, but either continue to serve them albeit in a lesser or indirect way, or that although it had moved away from their original objective, but the move required minimal or no additional resources devoted to the event. Significant mission drift is when social enterprise moves away from their original objective and no longer served those mission. 
Table 3. Descriptive statistics of the data

Type of stakeholder involvements ( $\mathrm{N}$ (Number of events)=80)

No stakeholder

Dormant

Complementary

Collaborative

Dominant

Type of external partners ( $\mathrm{N}=62$, can choose more than one)

Government bodies

Other social enterprises

For profit organisations

Donors

Affiliates 
Nature of product

$(\mathrm{N}=80)$

\section{No}

36

change

Extend 11

New

33
Nature of market

$(\mathrm{N}=80)$

No change

57

Expand

14

New

9
Mission drift ( $\mathrm{N}=80)$

No drift

61

Slight drift

14

Significant drift 5 
Table 4. Descriptions of selected bricolage events

\begin{tabular}{|c|c|}
\hline Event & Resource holder(s) \\
\hline \multicolumn{2}{|l|}{ Internal bricolage events } \\
\hline \multicolumn{2}{|l|}{ No partner's involvement } \\
\hline $\begin{array}{l}\text { INT1. Extend service from a physical location to one based in the } \\
\text { patient's own home (Hospice for All) }\end{array}$ & No partner \\
\hline $\begin{array}{l}\text { INT2. From providing business consultancy for social enterprises } \\
\text { providing training for social enterprises (Consultancy for Social } \\
\text { Change) }\end{array}$ & No partner \\
\hline $\begin{array}{l}\text { INT3. From individual student coaching to training that is targeting } \\
\text { the same market (Student Mentoring) }\end{array}$ & No partner \\
\hline \multicolumn{2}{|l|}{ Collective bricolage events } \\
\hline \multicolumn{2}{|l|}{ Dormant Resource Holder } \\
\hline $\begin{array}{l}\text { DOR1. Set up adult and children hospices through long-term local } \\
\text { fund-raising campaigns (Hospice for All) }\end{array}$ & Donors providing financial support \\
\hline $\begin{array}{l}\text { DOR2. Provide clothing and breakfast for homeless people through } \\
\text { donations (Homelessness Support) }\end{array}$ & Donors providing donated food and clothes \\
\hline
\end{tabular}


DOR3. Organise student events at universities where Student Social Action was previously unable to reach or had not been considered (Student Social Action)

\section{Complimentary Resource Holder}

COM1. Running new programmes for youth, including sports and mental health programmes (Disadvantaged Youth Support)

COM2. Held its students' entrepreneurship project competition in conjunction with partner's enterprise educator conference. The partnership enabled its participants to meet with experienced educators who could provide them with valuable entrepreneurship advices. (Student Social Action)

COM3. Exchange donated goods to increase their stocks (Health Research, Empowering Lives Worldwide)

COM4. Knowledge sharing with a number of health organisations in order to reduce cost of their activities such as material procurement

(Hearing Support, Hospice for All)

\section{Collaborative Resource Holders}

COL1. Collaborates with a partner to organise a book club, utilising the idea and experienced convenors from the partner (Homelessness Support)
A social enterprise working with educational establishments as an intermediary

Local social enterprises offering access to their facilities and expertise, in return Disadvantage Youth provides access to the premises, kitchens and coaches that it has

A social enterprise promoting entrepreneurial activities in universities.

Other social enterprises that have retail outlets

Other relevant health organisations

A social enterprise specialising in reducing social isolation 


\begin{tabular}{|c|c|}
\hline $\begin{array}{l}\text { COL2. Collaborates with partners to develop fairtrade and ethical } \\
\text { products, enabling them to increase revenues and expand their social } \\
\text { impact through bettering the lives of collaborators' target recipients. } \\
\text { (Empowering Lives Worldwide) }\end{array}$ & Social enterprises producing these products \\
\hline $\begin{array}{l}\text { COL3. Collaborates with the Job Centre to run weekly employability } \\
\text { workshops for homeless people (Homelessness Support) }\end{array}$ & Government's Job Centre \\
\hline $\begin{array}{l}\text { COL4. Collaborates with student counsellors and social workers to } \\
\text { provide relevant services (Homelessness Support) }\end{array}$ & Student volunteers that gain valuable work experience \\
\hline $\begin{array}{l}\text { COL5. Collaborates with a school in developing a training } \\
\text { programme for teachers to improve their ability to handle students } \\
\text { with stress and mental health issues. (Student Mentoring) }\end{array}$ & A School \\
\hline $\begin{array}{l}\text { COL6. Collaborates with a partner to deliver a stress management } \\
\text { workshop for those with noted mental health problem as part of the } \\
\text { art and music therapies. (Student Mentoring) }\end{array}$ & A mental health charity \\
\hline \multicolumn{2}{|l|}{ Dominant Resource Holder } \\
\hline $\begin{array}{l}\text { DOM1. Obtains a tender by the NHS to offer walk-in health care to } \\
\text { the general homeless population. The NHS provides medical } \\
\text { expertise to directly implement the programme (Homelessness } \\
\text { Support) }\end{array}$ & NHS \\
\hline $\begin{array}{l}\text { DOM2. Obtains a tender by the NHS to install a specific number of } \\
\text { hearing aid for its users, utilising their technical competencies as } \\
\text { audiologists }\end{array}$ & NHS \\
\hline
\end{tabular}


DOM3. Utilises the Empty Home Initiative to acquire empty properties for new supported accommodations for youth utilising the partner's financial incentives through EHI (Disadvantaged Youth Support)

DOM4. Utilises the Empty Home Initiative to acquire a derelict hotel as new supported accommodations for youth, plus a renovation grant. It utilises its pre-existing competencies as sheltered accommodation/ homeless support provider as well as homeware that was donated to its retail outlets. (Homelessness Support)

DOM5. Obtains a contract to offer additional supports to homeless ex-offenders. (Homelessness Support)
Local government

Same as above

Government and Prison Service 
Table 5. A summary of the impact of bricolage and collaboration on mission of social enterprises

\begin{tabular}{|c|c|c|c|c|c|}
\hline & Internal & $\begin{array}{l}\text { Dormant } \\
\text { The "Silent Partner" }\end{array}$ & $\begin{array}{l}\text { Complimentary } \\
\text { The "Respected Buddy" }\end{array}$ & $\begin{array}{l}\text { Collaborative } \\
\text { The "Business Partner" }\end{array}$ & $\begin{array}{l}\text { Dominant } \\
\text { The "Controlling } \\
\text { Parent" }\end{array}$ \\
\hline \multicolumn{6}{|c|}{ i) Relationship with Resource Holders } \\
\hline $\begin{array}{l}\text { Relationship } \\
\text { maintenance }\end{array}$ & $\mathrm{X}$ & Inform & Mutual respect & Negotiate & Compliance \\
\hline Freedom to implement & Full autonomy & Full autonomy & $\begin{array}{l}\text { Large autonomy when } \\
\text { interdependence is un- } \\
\text { complicated }\end{array}$ & $\begin{array}{l}\text { Co-create outcomes } \\
\text { can be restricted in the } \\
\text { case of goal } \\
\text { incongruence }\end{array}$ & $\begin{array}{l}\text { Restricted in the case } \\
\text { of goal incongruence }\end{array}$ \\
\hline Who are they? & $\mathrm{X}$ & $\begin{array}{l}\text { Mostly donor and } \\
\text { volunteers of for profit } \\
\text { organisations }\end{array}$ & $\begin{array}{l}\text { Mostly local; other } \\
\text { social enterprises }\end{array}$ & $\begin{array}{l}\text { Other organisations } \\
\text { especially social } \\
\text { enterprises }\end{array}$ & $\begin{array}{l}\text { Mostly governing } \\
\text { bodies }\end{array}$ \\
\hline \multicolumn{6}{|c|}{ li) Strategy and Approach } \\
\hline $\begin{array}{l}\text { Developmental } \\
\text { approach }\end{array}$ & Cost pragmatism & Idealism & Exchange pragmatism & $\begin{array}{l}\text { Co-creational } \\
\text { pragmatism }\end{array}$ & Relational pragmatism \\
\hline \multicolumn{6}{|l|}{ lii) Bricolage Outcomes } \\
\hline Scale & Small & Small to large & Small & Small to medium & Mostly large \\
\hline $\begin{array}{l}\text { Possible form(s) of } \\
\text { market and product } \\
\text { development }\end{array}$ & $\begin{array}{l}\text { Incremental market and } \\
\text { product development }\end{array}$ & $\begin{array}{l}\text { Incremental and radical } \\
\text { product and market } \\
\text { development }\end{array}$ & $\begin{array}{l}\text { Incremental and radical } \\
\text { product development }\end{array}$ & $\begin{array}{l}\text { More often radical } \\
\text { product development } \\
\text { and incremental market } \\
\text { development }\end{array}$ & $\begin{array}{l}\text { Radical product and } \\
\text { market development }\end{array}$ \\
\hline
\end{tabular}




\begin{tabular}{|l|l|l|l|l|l|}
\hline Mission drift & Not very likely & Not very likely & Not very likely & $\begin{array}{l}\text { Goal incongruence and } \\
\text { when resource holder } \\
\text { has stronger bargaining } \\
\text { power }\end{array}$ & $\begin{array}{l}\text { When financial concern } \\
\text { of social enterprise is } \\
\text { high, goal } \\
\text { incongruence can } \\
\text { cause serious mission } \\
\text { drift. On the other hand, } \\
\text { goal congruence can } \\
\text { prohibit change }\end{array}$ \\
& & & & \\
\hline
\end{tabular}


Figure 1. Resource dependency and nature of partnership between social enterprises and stakeholders

\section{Dominant partner}

- resource holder holds power and involve in the development of the social event

- resource holder who has clear objectives would take control to ensure that these are implemented

\section{Integrated}

involvement (active)

\section{Collaborative partner}

- two mutually dependent parties work collaboratively in an integrated project

- relatively great degree of process integration to co-create social outcome

\begin{tabular}{|c|c|c|}
\hline $\begin{array}{l}\text { Asymmetric } \\
\text { power/ }\end{array}$ & & $\begin{array}{l}\text { Symmetric } \\
\text { power/ }\end{array}$ \\
\hline stakeholder & & mutually \\
\hline $\begin{array}{l}\text { dependence } \\
\text { Dormant partner }\end{array}$ & Complementary partner & dependence \\
\hline
\end{tabular}

- resource holder holds power over the social enterprise but has no integrative involvement in its operation
- Two parties mutually dependent on each other in a transactional based relationship

- often offers complementary products and services

- cooperation would enable them to exploit each other's relative strengths 
Figure 2- Conceptual framework

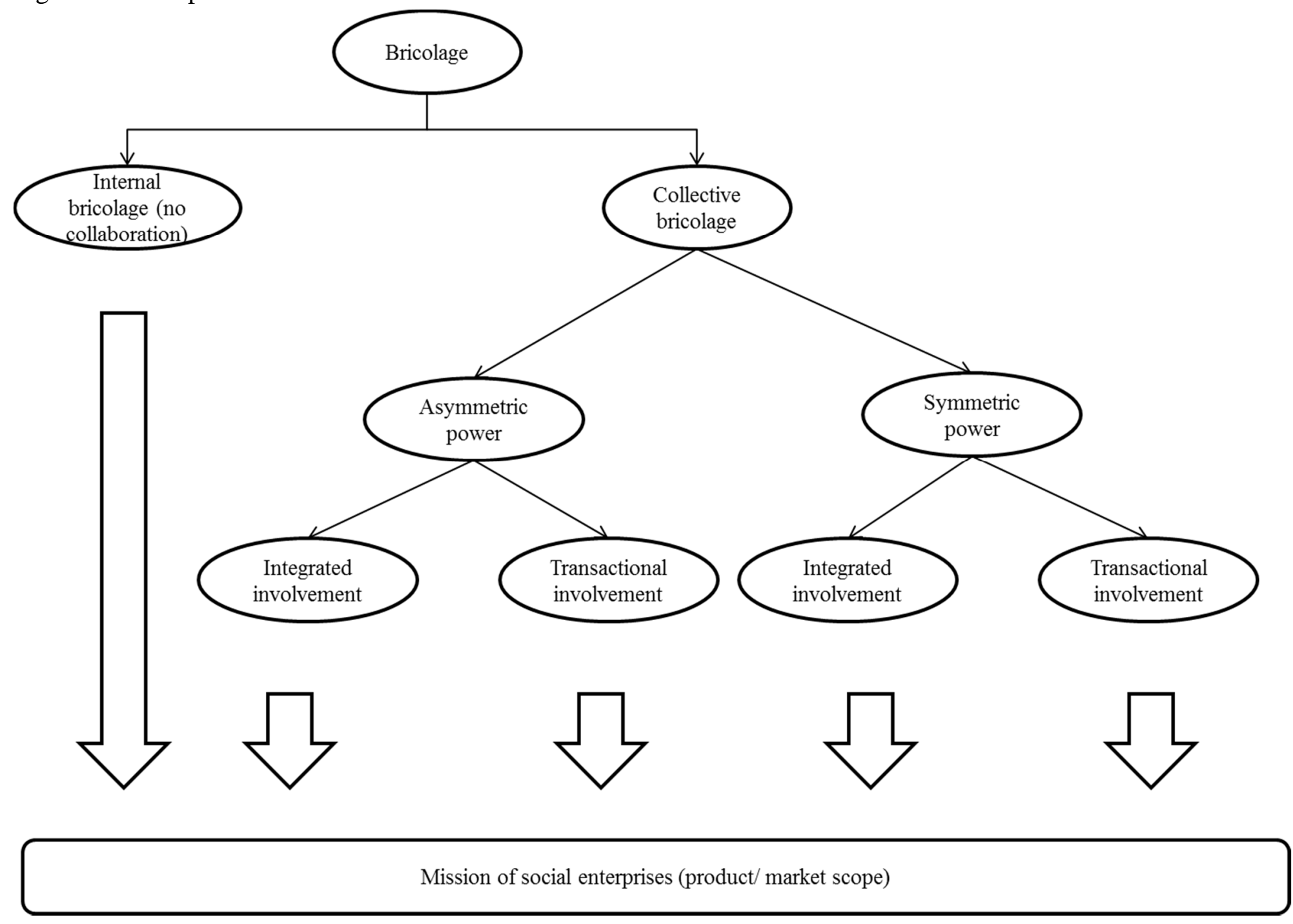


